\title{
Biological Effects of Exposure to High Frequency Electromagnetism on Rabbits and Guinea Pigs
}

\author{
Yoshiko AOYAMA, Yasushi UEDA, Motohiko KURITA, Hidenori OHASHI*, \\ Chikao TORIGATA**, and Kazuyoshi MAEJIMA***

\begin{abstract}
Animal Care Co., Ltd., 3-47-11 Nakano, Nakano-ku, Tokyo 164, *Department of Veterinary Pharmacology, Faculty of Agriculture, Gifu University, 1-1 Yanagido, Gifu-shi, Gifu 501-11, ** Department of Pathology, School of Medicine, Keio University, 35 Shinanomachi, Shinjuku-ku, Tokyo 160, and ${ }^{* * *}$ Laboratory Animal Center, School of Medicine, Keio University, 35 Shinanomachi, Shinjuku-ku, Tokyo 160, Japan
\end{abstract}

(Received 18 November 1991/Accepted 8 May 1992)

To investigate the biological effects of exposure to feeble high frequency electromagnetism, skin surface temperature, blood vessel (arterioles and venules) diameter were examined, using infrared thermography, a laser doppler flowmeter, and a video macroscope, respectively, in the ear of rabbits. After exposing the ear of rabbits to high frequency electormagnetism value of $9 \mathrm{MHz}$ for 15 minutes, continued rising of local temperature was demonstrated. Though dilatation of arterioles was not seen. In addition, venules tended to dilate and blood flow also to increase, and microcirculation was accelated at the site where electromagnetism was exposed. Hazardous effects of long term exposures of high frequency electromagnetism ( $9 \mathrm{MHz}$ for 30 days, 8 hours/day) on guinea pigs were not observed in their behavior, food consumption, body and organ weights, hematological and biochemical values, macroscopic and microscopic findings on autopsy. - KEY WORDS : electromagnetism, guinea pig, microcirculation, pathology, rabbit

\section{高周波電磁界照射のウサギ局所循環および \\ モルモット皮下組織に及ぼす影響}

青山美子 - 植田康志 - 栗田源彦 ·大橋秀法*

鳥潟 親雄 ${ }^{* *} \cdot$ 前島一淑***

\footnotetext{
株式会社アニマルケア

*岐阜大学農学部家畜薬理学教室

**慶応義塾大学医学部病理学教室

***慶応義塾大学医学部実験動物センター
}

我々は, 現在, 家庭電化製品等を発生源とする種々の 高周波電磁界に囲まれて生活している。電磁界のヒト に及ぼす影響については, Tompkins [27] やWilson [32］らによって危険性が指摘されているが，一方，生 体への影響を積極的に医療へ応用していくことも検討さ
れている。

実験動物施設内の高周波電磁界の影響については, 電 磁界強度を測定した資料はないが, 空調機器や各種の計 測機器, 電気メス等の実験器具から，それぞれ異なった 強度の高周波電磁界が発生していると思われ，実験動物 

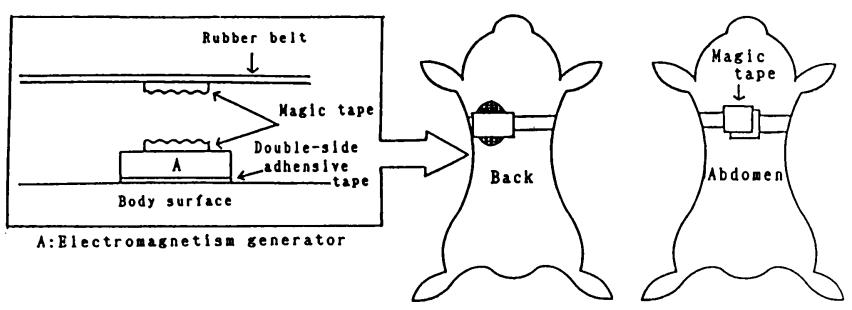

Fig. 1. Attachment of a high frequency electromagnetism generator

が日常的に電磁界に曝されているものと予測される。

又, 今後, 実験動物施設で作業する人々の間に労衝衛生 上の問題が生じる可能性もあろう。

ともあれ高周波電磁界の生体に及ぼす影響について は, 臨床応用面での検討が先行し, 基礎的な研究は緒 についたばかりである。臨床的な試みでは，すでに1891 年, Teslaにより温熱効果があることが見いだされ，翌 年, 効果としては疑問とされたが, d'Arsonvalによ って医療に応用されている $[15,26]$ 。その後 1925年に Schlleiphake が超短波高周波電磁界による治療を試み [26]，1940年代の Ginsberg [7]による臨床応用に関す る研究を契機に, 血腫の分解促進 [5], 骨折の治癒促進 [2], 肩こりの改善 [22] 等が確認され，高周波電磁界 照射による治療が広がった。この高周波電磁界の生体に 対する作用として温熱作用と血行促進が挙げられている が，その作用機序に関しての詳細は未だ確認されていな い。又, 生体に対する侵襲性についての動物実験データ [31] を総覧しても十分な情報を我々に提供していると はいい難い。将来, 超伝導物質等の実用化によって, 実 験動物もヒトも，さらに強い高周波電磁界に曝されるも のと予測されるので, 動物実験上ならびにヒトの衛生学 上の問題として検討しておくことが必要である。又, 高 周波電磁界の医療への応用についても基礎データを集積 しておくことが望ましい。

そこで著者らは, 高周波電磁界が生体に及ぼす影響 を，一般的な生活環境における電磁界の周波数 $[23,30]$ より高く，医療用にむ応用されている周波数 $9 \mathrm{MHz}$ の 高周波電磁界発生装置によりウサギおよびモルモットを 用いて, 特に局所の微小循環と組織学的反応を中心に検 討した。

\section{材料および方法}

動物 : $25 \mathrm{~kg}$ の雄及び䊒ウサギ（日本白色種, クリー
ソ，日本医科学動物資材） 24 羽，並びに， $350 \mathrm{~g}$ の雄及 び倠モルモット（ハートレー，クリーン，ハムリー） 18 匹を用いた。雔雄は同匹数ずつ用いた。いずれの動 物む, 温度 $24 \pm 1{ }^{\circ} \mathrm{C}$, 湿度 $55 \pm 5 \%$, 12時間明（8２0 時）12時間暗（20〜8時)，70\%リターンェアの動物実 験室において，ステンレススチール製金網ケージ（ウサ ギ用: $300 \mathrm{~W} \times 500 \mathrm{D} \times 320 \mathrm{Hmm}$, モルモット用: $350 \mathrm{~W}$ $\times 420 \mathrm{D} \times 230 \mathrm{Hmm}$, 日本クレア）に収容し，実験に供 した。飼料はウサギ用固形飼料 CR-1（日本クレア）お よびモルモット用固形飼料 CG-3（日本クレア）を用 い, 飲水は自動給水装置によってフィルター洰過後の水 道水を与えた。

高周波電磁界発生装置: 高周波電磁界発生装置（オム ロン株式会社，以下高周波装置）を用いた。この装置 は, コルピッツ発振回路を IC 制御する出力方式に基づ き, $3 \mathrm{~V}$ Vリチウムボタン電池を電源として $9 \mathrm{MHz}$ の 交番磁界を間欠発生させることがでさる。コイル部は直 径 $27 \mathrm{~mm}$ の円形状で, 中央に径 $8 \mathrm{~mm}$ の穴があいてい る。発振回路内臓の電源部 (以下, 電源部) は長径 40 $\mathrm{mm}$, 短径 $33 \mathrm{~mm}$, 厚さ $7 \mathrm{~mm}$ の棈円形状である。尚, ウサギを用いた微小循環に関する実験では、コイル部と 電源部の分離型を用い, 装固電源の OiN/OFF は操作時 の動物に対する生理的影響を除去するため, 電源部のリ チウムボタン電池の着脱による遠隔操作で行った（動作 表示はLEDの点滅により確認)。高周波装置は, 両面粘 着テープ（住友スリーェム）を用いて動物の皮庙に装着 した。モルモットに対する安全性試験では, 高周波装置 を Fig. 1のように側腹部に装着し、コイル部と電源部 の一体型を用い, リチウムボタン電池の装着方向を入れ 換えることによって電源の ON/OFF操作とした。装着 時間は午前10時から午後 6 時まで毎日 8 時間とした。 又, 各実験実施の前後には, 高周波出力チェッカー（オ ムロン株式会社）で出力のチェックを行った。装着接 着面に拈ける電磁界の周波数は, ウサギ，モルモット共 


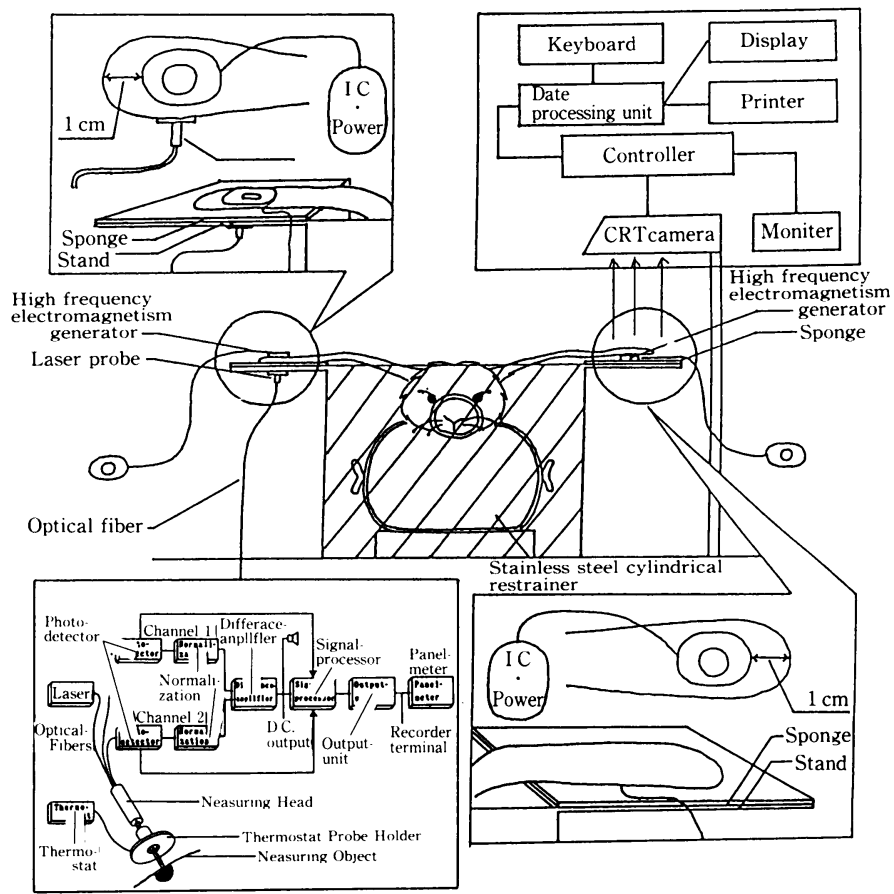

Fig. 2. Measurement of skin surface temperature and blood flow

に $9 \mathrm{MHz}$ である。

実験前処置：ウサギにおいては，30日間の予備飼育期 間の間に，毎日 2 回/ 1 匹（1 回につき 1 時間，延べ 60 時間) ステンレススチール製円筒型保定器に保定し, 実 験環境, 特に実験固定, 空調系統, 実験機器から発する 音, 照明等に馴化させた。実験実施の前日に, 高周波装 置を装着する部位（左右耳介）をチオグリコール酸カル シウム剤（エバクレーム $\mathrm{S} R$, 田辺製薬）を用いて除毛 し，更に，実験開始の 2 時間前から絶食をさせたが，飲 水は制限しなかった。又, ウサギの特異な習性である食 粪 [11] については，その抑制をとくに考慮することは しなかった。モルモットでは, 実験開始前日及び実験期 間中, 5 日に 1 回の割合でウサギで使用した脱毛剂を用 い, 装着部位およびその周辺の除毛を行った。

皮覤表面温度：ウサギ左耳介の先端より $1 \mathrm{~cm}$ 下の裏 側皮膚に両面粘着テープを用いて高周波装置を装着し， 耳介表側の皮膚表面温度を赤外線熱像図装置（インフラ アイ 160-201U型データ処理装置, 富士通）を用いて測 定した。動物の心理的動摇の抑制を考虑 [1] して, 目 隠しを兼ねた耳介固定台を段ボール紙で作製し，耳介が 固定台と接触する部分には熱の放散 [20］を押さえるア
ブゾーバーとしてスポンジを挟み込み，耳介を固定した (Fig. 2)。皮唐表面温度の測定は, 高周波装置のコイ ル部の中心にある穴の部分にカーソルを位置し，コイル 装着面に対して 5 点で行った。実験群では，高周波電磁 界出力 OFFで15分, ON で15分, 再び OFFで15分, 計 45分, 対照群では出力 OFF の状態で45分, それぞれ連 続測定した。熱像図装置の情報処理による記録は, 実験 群, 対照群ともに测定開始より 3 分毎に 1 匹あたり15画 像を入力し, 平均温度を経時的に測定した。尚, 成績記 載にあたっては, 対照群における経時的な測定の経過 (全測定時間45分) を15分ずつ 3 等分して, 実験群と同 様に照射前，照射中，照射後と表現した。

皮虐血流量 : ウサギ右耳介の先端より $1 \mathrm{~cm}$ 下の表側 皮膚に両面粘着テープを用いて高周波装置を装着し， 耳介裏側の皮膚血流量をレーザードップラー血流計 （PERIFLUX 囚，キャノン）を用いて測定した。測定 部位はFig. 2 に図示したように, 高周波装置のコイル 部中心の直下とし，そこにレーザープローブ ( $6 \mathrm{~mm} \phi$ $\times 30 \mathrm{~mm}$, 測定領域 : 直径 $1 \mathrm{~cm}$, 深さ $0.5 \sim 1 \mathrm{~mm})$ を 装着した。血流計の調整はアーチファクトフィルター を用い, タイムコンスタント，1.5秒，周波数限界， 12 


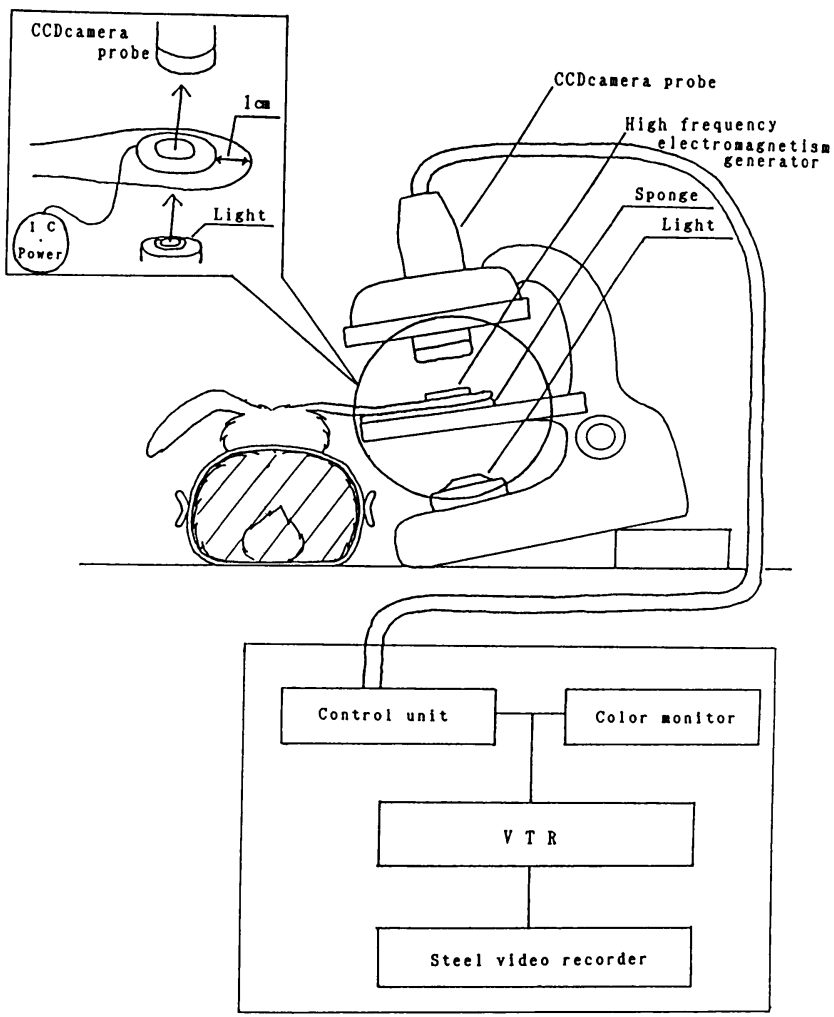

Fig. 3. Measurement of blood vessel diameter

$\mathrm{KHz}$, 記録感度, $\times 3$, チャート速度, $10 \mathrm{~cm} / \mathrm{min}$ とし た。血流量は記録感度 $(\times 3)$ 時の $10 \mathrm{~V}$ の振れを $100 \%$ とする相対量で表示した。測定は皮唐表面温度の測定と 同時に行ったので，測定環境，測定時間等は温度測定の それらと同じである。

細動静脈血管径: ウサギ右耳介を光学顕微鏡 $(\mathrm{BH}-2$, オリンパス）の載物台に両面粘着テープで固定し，対物 レンズリボルバーを取り外した後，マクロスコープのプ ローブ（200倍レンズ, 観察視野: $1.3 \mathrm{~mm} \times 1 \mathrm{~mm}$, 被 写界深度 $0.6 \mathrm{~mm}$ ）を装着した。まず，カラーモニター で細動脈, 細静脈が同一視野に入る位置を定めた後, プ ローブを固定し，次に、コイル部中心にある穴の部分を ウサギ右耳介先端 $1 \mathrm{~cm}$ 下に装着した（Fig. 3)。顕微 鏡本体は，ウサギ耳介の血管に物理的な圧迫を与えない 角度を保って設置した。測定はビデオマクロスコープ （VMS-1300，日本光電）を用い，可動式スケールによ り 3 分毎に行った。測定時には, 顕镫鏡の光源を最大に して透過させるので, プローブ本体の光源は OFF とし た。尚, 測定は皮庙表面温度ならびに皮唐血流量の測定
をすべて終了した後に行ったが, 測定環境, 測定時間等 は温度, 血流量のそれらと同じである。

行動：モルモットにおいて高周波装置装着による異物 感や高周波電磁界の体内発熱作用によるなんらかの反応 が日常行動に現れるか否かを知るため, 全個体の行動,

外観を毎日午後 1 時に観察した。

体重打よび飼料摂取量：モルモットの全個体につい て, 5 日おきに午前 9 時 30 分から午前10時までの間に体 重および飼料摂取量を測定した。飼料摄取量は，測定前 日の午前 9 時より翌午前 9 時までの24時間で測定した。

剖検: 実験終了後, モルモットについては，0.12g/ $\mathrm{ml} / 100 \mathrm{~g}$ 一体重のカルバミン酸ェチル（ウレタン，東 京化成）溶夜を腹腔内に投与し，深麻酔下で開腹して後 大静脈扣よび腹大動脈から全採血した後，全個体を解剖 に付した。主要臓器について, 肉眼的観察を行うととも に, 臓器重量を測定した。又，実験を終了したウサギに ついても血夜生化学検査用の血液として全個体の耳介静 脈から採血した。

病理組織学的検査：モルモット剖検時に、高周波装置 


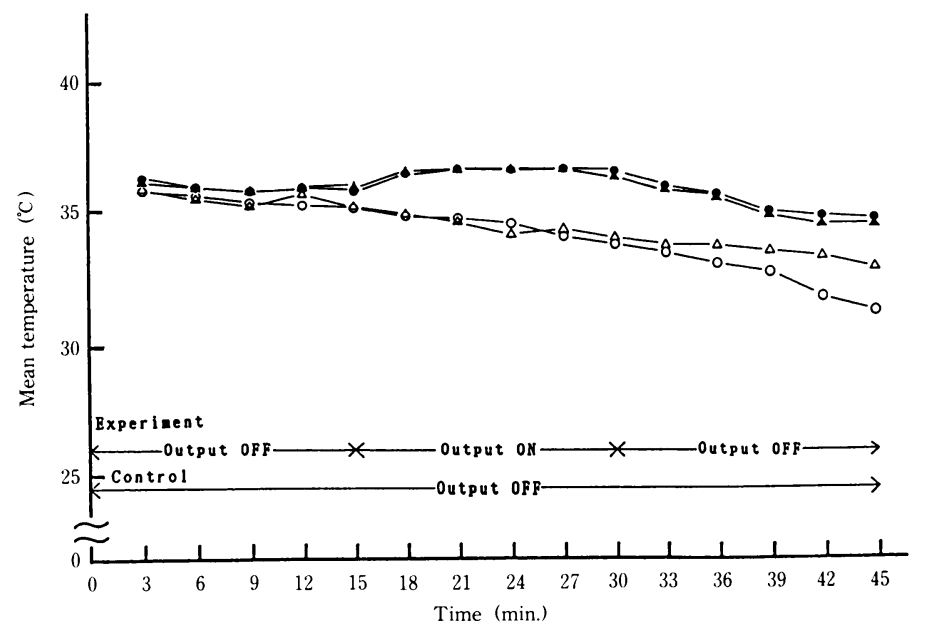

Fig. 4. Skin surface temperture of the ear of rabbits experiment; male: $-\mathrm{O}$ female:- $\mathbf{\Delta}-$ control; male: $-\mathrm{O}$ female : $-\triangle-$

の装着部位 (Fig. 1 参照) とその周辺部の組織を切取 り，10\%ホルマリン溶夜に投じて固定した。すべての個 体について，装置を装着した中心部とその周辺部の固定 組織それぞれ 2 力所の切片標本を作り,ヘマトキシリン エオジン染色を施し, 光学顕微鏡下で観察した。

血液生化学検査: 検査は, 剖検時あるいは実験終了時 に採取したウサギおよびモルモットの血夜を対象とし て, 生化学検査用オートアナライザー（VISION システ $\Delta(\mathbb{B}$, ダイナボット) 用い, へモグロビン $(\mathrm{Hb})$, へマ トクリット $(\mathrm{Ht})$, 総蛋白 $(\mathrm{TP})$, トランスアミナーゼ $(\mathrm{GOT} \cdot \mathrm{GPT})$, 乳酸脱水素酵素 $(\mathrm{LDH})$, アルカリ性 フォスファターゼ (ALP), クレアチンキナーゼ (CK), グルコース (Glu), トリグリセライド $(\mathrm{TG})$, コレス テロール (Chol), 尿酸 (UA), カルシウム $(\mathrm{Ca}), \mathrm{C}$ 反応性タンパク (CRP) について行った。

統計学的処理 : 各測定結果は平均值士標準偏差で表 し，有意差検定は，Student's-t 検定によった。

\section{成 継}

1.ウサギの微小循環に関する検討 : 実験群（雌雄各 6 羽) および対照群 (雌雄各 6 羽) 計24羽のウサギの耳 介皮店表面温度, 皮膚血流量就よび細動静脈血管径の変 化を測定することによって, 高周波電磁界が微小循環に 及ぼす影響を検索した。実験群では，高周波電磁界の照
射前15分, 照射中15分および照射後15分の合計 45 分間測 定し, 対照群では同時期に合計45分間（表現上照射前, 中，後と分けて記述）測定した。

Fig. 4 には, 各個体とも5 ヶ所の左耳介皮虐表面温 度を測定した平均値が示されている。実験群では, 高 周波電磁界を照射する前の15分間では, 雄の皮庯表面温 度は35. $78 \pm 0.48^{\circ} \mathrm{C}$, 雌では $35.70 \pm 0.33^{\circ} \mathrm{C}$ であったが, 照射中の 15 分では雄が $36.70 \pm 0.39^{\circ} \mathrm{C}$, 倠が $36.64 \pm 0.31$ ${ }^{\circ} \mathrm{C}$ となり，照射を止めた後の 15 分では雄が $35.23 \pm 1.10$ ${ }^{\circ} \mathrm{C}$, 雌が $34.54 \pm 2.29^{\circ} \mathrm{C}$ となった。照射しなかった対照 群においては, 実験群に対応する照射前, 中, 後の皮唐

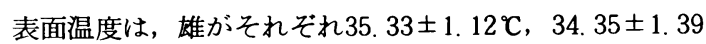
${ }^{\circ} \mathrm{C}, 32.44 \pm 2.71{ }^{\circ} \mathrm{C}$, 雌が $35.50 \pm 0.82^{\circ} \mathrm{C}, 34.30 \pm 1.40$

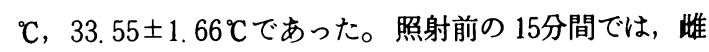
雄ともに実験群と対照群の間に有意差は認められなかっ たが，照射中の15分間では，雌雄ともに実験群の皮唐 表面温度が対照群のそれより有意に上昇していた（ $\mathrm{p}<$ 0. 05)。又, 実験群の照射中の皮廂表面温度は, 照射前 および照射後の皮膚表面温度に対して, それぞれ有意に 高い数值を示していた（p<0.05）。実験群と対照群と の比較では, 照射開始より 15 分後の平均値で $2.6^{\circ} \mathrm{C}$, 照 射終了 15 分後では $2.7^{\circ} \mathrm{C}$ の差が観察された。なお，皮有 表面温度に関して, 性差は認められなかった。Fig. 5 は皮屇表面温度の変化を, 赤外線熱像図装置のカラーモ ニターで出力した実験群個体における1例である。 


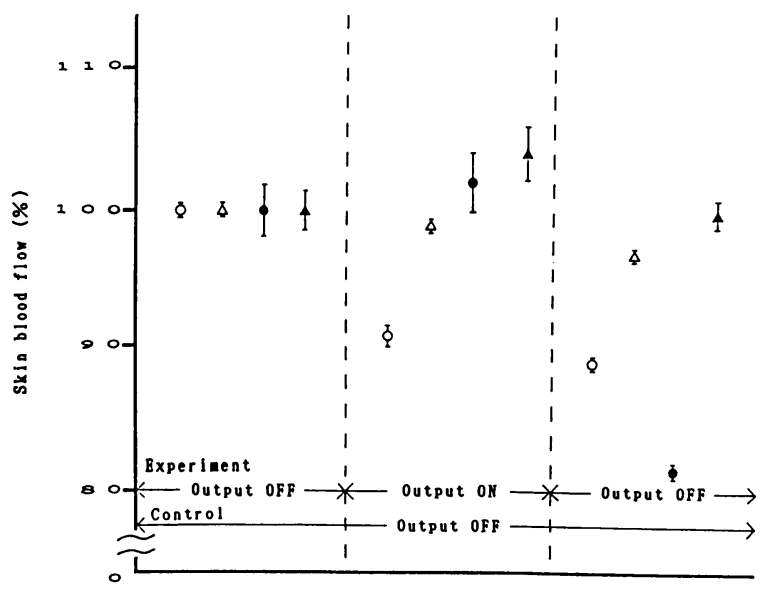

Fig. 6. Skin blood flow of the ear of rabbits experiment ; male : $-\mathbf{O}$ - female : $-\boldsymbol{\Delta}-$ control ; male : $-\bigcirc-$ female : $-\triangle-$

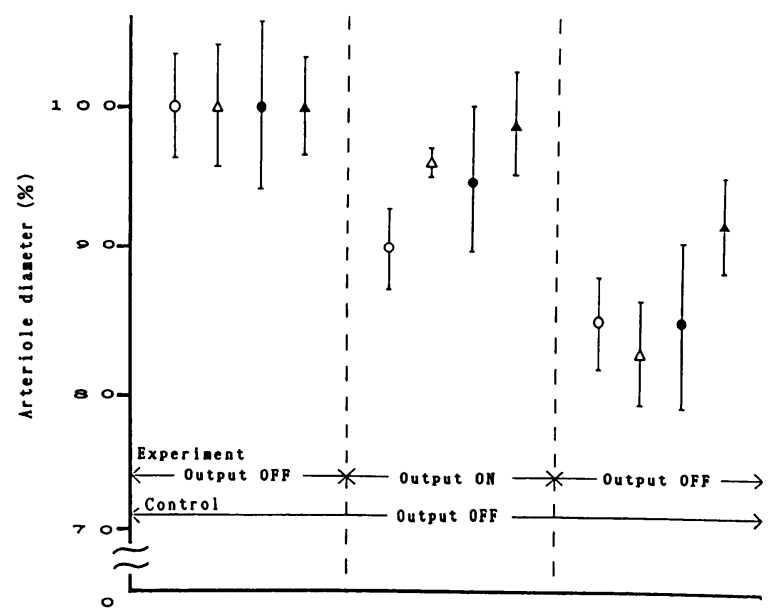

Fig. 7. Ear arteriole diameter of rabbits experiment; male : - - female : $-\boldsymbol{\Delta}-$ control ; male : $-\bigcirc-$ female : $-\triangle-$

Fig. 6 では，レーザードップラー血流計によって測 定したウサギ右耳介の皮膚血流量を照射前15分間を基準 （100\%）とした百分率で表した。実験群では，照射を開 始すると (照射中), 雄の血流量は $101.99 \pm 0.96 \%$, 雃 は104. 48土0.88\%となり，照射を中止すると(照射後), 雄の血流量は $81.59 \pm 0.19 \%$ ，雌は $99.50 \pm 0.53 \%$ とな った。一方, 照射しなかった対照群の照射中, 後の血

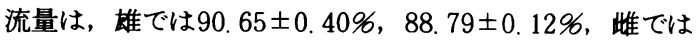

98. $85 \pm 0.17 \% ， 96.55 \pm 0.19 \%$ でった。実験群におい て皮庙血流量は照射によって增加，照射中止によって減 少の傾向を示したが，照射前と比較して照射中および照 射後の間に有意差は認められなかった。対照群の皮唐血 流量は, 測定開始後に連続的に減少した。血流量に性差 は認められなかった。

ビデオマクロスコープを用いて細動静脈血管径の変化 を測定した。結果はFig. 7，8に示したよ5に，高周 


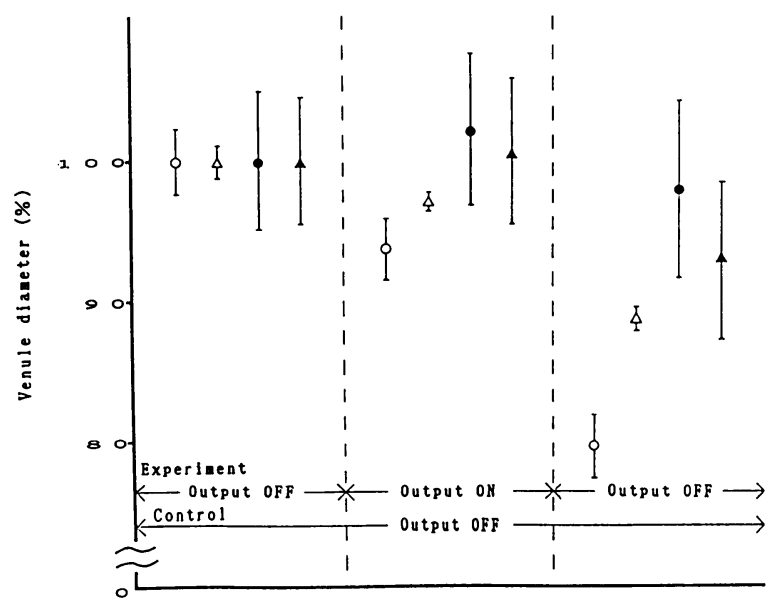

Fig. 8. Ear venule diameter of rabbits experiment; male : - female: $-\mathbf{\Delta}-$ control ; male : $-\bigcirc-$ female : $-\triangle-$

Table 1. Hematological and biochemical values of rabbits

\begin{tabular}{|c|c|c|c|c|c|c|c|c|c|}
\hline & \multirow{3}{*}{ Item } & \multicolumn{4}{|c|}{ Experiment } & \multicolumn{4}{|c|}{ Control } \\
\hline & & \multicolumn{2}{|c|}{ Male } & \multicolumn{2}{|c|}{ Female } & \multicolumn{2}{|c|}{ Male } & \multicolumn{2}{|c|}{ Female } \\
\hline & & Mean & $\mathrm{SD}$ & Mean & $\mathrm{SD}$ & Mean & SD & Mean & $\mathrm{SD}$ \\
\hline $\mathrm{Hb}$ & $(\mathrm{g} / \mathrm{d} \ell)$ & 7.12 & 0.17 & 8.02 & 1.68 & 7.50 & 1.19 & 7.42 & 1.18 \\
\hline $\mathrm{Ht}$ & $(\mathrm{g} / \mathrm{d} \ell)$ & 44.67 & 1.86 & 44.67 & 1.86 & 45.00 & 1.67 & 44.83 & 1.72 \\
\hline $\mathrm{TP}$ & $(\mathrm{g} / \mathrm{d} \ell)$ & 6.28 & 0.37 & 6.63 & 0.34 & 6.78 & 0.44 & 6.40 & 0.42 \\
\hline ALP & $(\mathrm{IU} / \ell)$ & 6.53 & 1.32 & 7.22 & 1.81 & 8.37 & 1.44 & 8.30 & 2.12 \\
\hline GOT & $(\mathrm{IU} / \ell)$ & 46.40 & 16.87 & 33.83 & 10.23 & 48.05 & 8.46 & 54.45 & 10.56 \\
\hline GPT & $(\mathrm{IU} / \ell)$ & 40.82 & 14.25 & 56.77 & 19.01 & 44.67 & 14.62 & 53.75 & 16.18 \\
\hline $\mathrm{LDH}$ & $(\mathrm{IU} / \ell)$ & 68.30 & 96.66 & 454.92 & 79.82 & 511.47 & 90.68 & 499.35 & 111.86 \\
\hline $\mathrm{CK}$ & $(\mathrm{IU} / \ell)$ & 13.18 & 119.49 & 498.30 & 71.09 & 476.95 & 56.90 & 568.02 & 105.96 \\
\hline TG & $(\mathrm{mg} / \mathrm{d} \ell)$ & 61.20 & 7.33 & 64.57 & 8.04 & 67.60 & 9.67 & 65.07 & 13.15 \\
\hline Chol & $(\mathrm{mg} / \mathrm{d} \ell)$ & 18.70 & 5.09 & 39.62 & 10.82 & 39.75 & 11.71 & 44.70 & 19.96 \\
\hline Glu & $(\mathrm{mg} / \mathrm{d} \ell)$ & 39.47 & 20.53 & 118.88 & 17.32 & 125.02 & 13.50 & 122.22 & 18.50 \\
\hline CRP & $(\mathrm{mg} / \mathrm{d} \ell)$ & 0.25 & 0.30 & 0.13 & 0.18 & 0.40 & 0.40 & 0.23 & 0.34 \\
\hline UA & $(\mathrm{mg} / \mathrm{d} \ell)$ & 0.98 & 0.76 & 1.48 & 0.42 & 1.18 & 0.64 & 1.28 & 0.31 \\
\hline $\mathrm{Ca}$ & $(\mathrm{mg} / \mathrm{d} \ell)$ & 14.33 & 0.88 & 13.45 & 1.52 & 14.57 & 3.94 & 15.48 & 0.89 \\
\hline
\end{tabular}

波電磁界照射前の平均值を基準（100\%）とすると，細 動脈において，照射中の実験群の血管径は，雄で 94.52 $\pm 5.33 \%$ ，倠は $99.02 \pm 3.51 \%$ となり，照射を中止する と (照射後), 雄では $84.62 \pm 5.73 \%$, 雌は $91.59 \pm 3.67$ 写となった。照射しなかった対照群の照射中, 後の細動

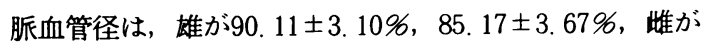
$96.41 \pm 0.59 \% ， 82.82 \pm 3.53 \%$ であった。両群そして両
性ともに，照射前との比較において照射中および照射後 の間に有意差は認められなかったが，測定開始とともに 連続して減少する傾向を示した。又, 細静脈について は, 照射中の実験群の血管径は, 雄で 102.20土5.38\%, 倠は $100.30 \pm 5.16 \%$ となり, 照射を中止すると（照射 後), 雄では $98.38 \pm 6.36 \%$, 雌は $93.15 \pm 5.55 \%$ となっ た。照射しなかった対照群の照射中, 後の血管径は, 雄 


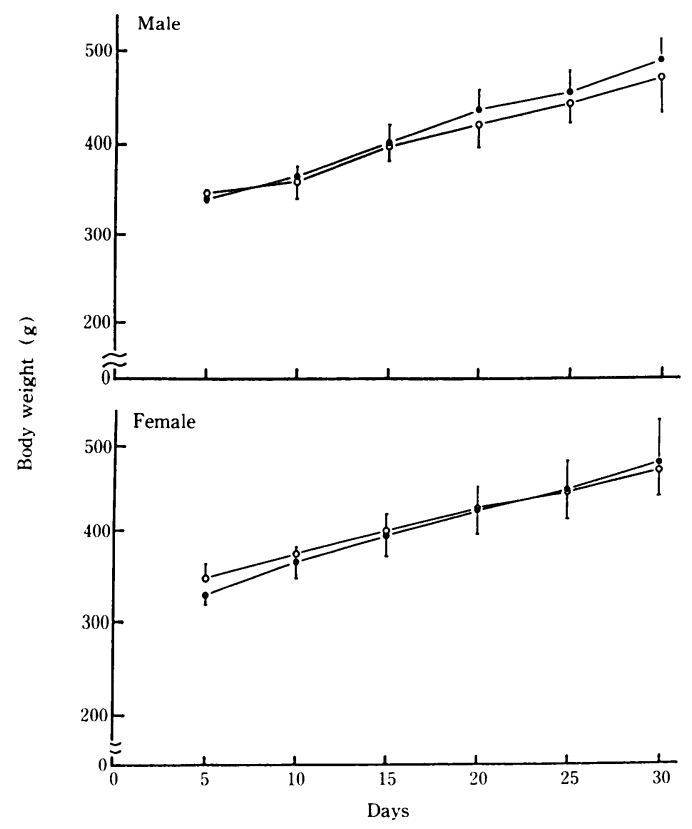

Fig. 9. Body weight of guinea pigs experiment ; - - control ; - $\mathrm{O}-$

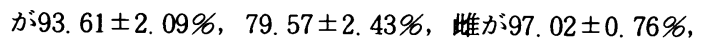
89.07士0.92\%であった。実験群においては両性ともに, 細静脈血管径は照射開始によって抬張, 照射中止によっ て収縮の傾向を示したが，統計学的な有意差は認められ なかった。照射しなかった対照群においては，測定開始 とともに血管が連続的に収縮する傾向を示した。

高周波電磁界照射実験の全測定終了後にすべてのウサ ギについて, 全個体の耳介静脈より採血し, 血液生化学 的検索を行った。結果を Table 1 に示したが, 測定項 目のすべてにわたり, 実験群と対照群の間に有意差はみ られず, 又, 正常值 $[11,19]$ の範囲内にあった。

2.モルモットに拈ける組織学的反応：18匹のモルモ ットを 2 群に分け，実験群に12匹，対照群に 6 匹を当て た（両群とも倠雄同匹数）。実験群では, 高周波電磁界を 午前10時から午後 6 時まで毎日 8 時間ずつ, 30 日間照射 した。対照群にも高周波装置を装着したが，電源は OFF のままにした。

照射実験期間中, 毎日の行動観察でモルモットは行動 に異常を認めることなく, 又, 5 日間隔で行った飼料摄 取量および体重の測定値についても両群間に有意差はみ られなかった（Fig. 9，10）。

照射実験開始31日目にウレタン麻酔下の全採血によっ

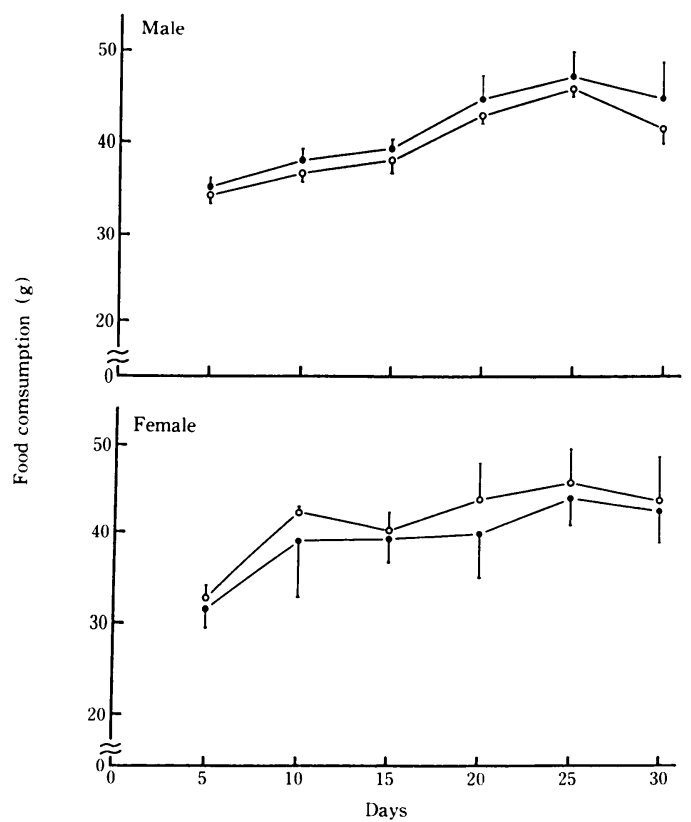

Fig. 10. Food comsuption of guinea pigs experiment ; - - control ; -

て安楽死させたモルモットを全例病理解剖に付した。実 験群，対照群の別を問わず，ほとんどのモルモットはやや 肥満傾向にあり，栄養状態は良好で，発育状態に異常は 認められなかった。対照群を含めて, 側腹部における高 周波装置の装着部位ならびにその周辺部位では皮局層, 筋層でよく弾力性が保たれていた。又, 負血もみられなか った。全身リンパ節を含む各臓器の位置, 形態, 表面の状 態, 色調, 内容物等に異常は認められなかった。但し, 実 験群12匹中の 3 匹及び対照群の 6 匹中 2 匹の肺和よひ胸腺 に小出血斑がみられたが，これらはウレタン麻酔によるも のと思われた。Table 2 に各喊器重量を示したが, 実験 群と対照群の間に有意差は認められなかった。又, ここ で得られた数値は, 健康なモルモットの標準的な葴器重 量（体重比）［16］とよく一致していた。Table 3 に血液 生化学的検査値を示したが，これらの数值はすべて両群間 に有意差はなく, 又, 正常值 $[16,19]$ の範囲内にあった。 剖検したモルモットの高周波装置を装着した側腹部局 所の皮庙について組織学的検索を行った。表皮, 真皮お よび皮下組織の 3 層において, 実験群, 対照群ともに出 血, 浮腫, 炎症等による細胞浸潤あるいは萎縮等は観察 されなかった。真皮下の皮下組織において，結合組織や 脂肪組織からなる眯性結合組織と層内に存在している大 
Table 2. Mean organ weights of rabbits (per 100g body weight)

\begin{tabular}{|c|c|c|c|c|c|}
\hline \multirow{2}{*}{ Organ } & & \multicolumn{2}{|c|}{ Experiment } & \multicolumn{2}{|c|}{ Control } \\
\hline & & Mean & SD & Mean & SD \\
\hline Heart & $(g)$ & 0.31 & 0.01 & 0.30 & 0.04 \\
\hline Lungs & (g) & 0.53 & 0.05 & 0.54 & 0.08 \\
\hline Spleen & (g) & 0.09 & 0.02 & 0.10 & 0.01 \\
\hline Pancreas & (g) & 0.29 & 0.08 & 0.32 & 0.07 \\
\hline Liver & $(g)$ & 3.21 & 0.29 & 3.22 & 0.34 \\
\hline Stomach & (g) & 0.79 & 0.05 & 0.85 & 0.12 \\
\hline Small and large Intestine & (g) & 6.36 & 0.84 & 6.53 & 1.36 \\
\hline Kidneys & $(\mathrm{g})$ & 0.74 & 0.05 & 0.72 & 0.06 \\
\hline Epididymes & $(\mathrm{mg})$ & 43.75 & 11.61 & 47.90 & 6.90 \\
\hline Testes & (g) & 0.40 & 0.04 & 0.45 & 0.04 \\
\hline Vesicles & (g) & 0.17 & 0.06 & 0.21 & 0.16 \\
\hline Ovaries & (mg) & 12.13 & 2.99 & 15.83 & 3.62 \\
\hline Uterus & (g) & 0.24 & 0.02 & 0.20 & 0.04 \\
\hline Adrenal glands & $(\mathrm{mg})$ & 47.34 & 9.84 & 48.64 & 6.43 \\
\hline
\end{tabular}

Table 3. Hematological and biochemical values of guinea pigs

\begin{tabular}{|c|c|c|c|c|c|c|c|c|c|}
\hline & \multirow{3}{*}{ Item } & \multicolumn{4}{|c|}{ Experiment } & \multicolumn{4}{|c|}{ Control } \\
\hline & & \multicolumn{2}{|c|}{ Male } & \multicolumn{2}{|c|}{ Female } & \multicolumn{2}{|c|}{ Male } & \multicolumn{2}{|c|}{ Female } \\
\hline & & Mean & $\mathrm{SD}$ & Mean & SD & Mean & $\mathrm{SD}$ & Mean & $\mathrm{SD}$ \\
\hline $\mathrm{Hb}$ & $(\mathrm{g} / \mathrm{d} \ell)$ & 11.72 & 1.30 & 9.68 & 0.51 & 9.87 & 0.21 & 10.70 & 0.66 \\
\hline $\mathrm{Ht}$ & $(\mathrm{g} / \mathrm{d} \ell)$ & 52.83 & 3.37 & 52.66 & 3.20 & 48.75 & 4.99 & 53.00 & 2.65 \\
\hline $\mathrm{TP}$ & $(g / d \ell)$ & 4.15 & 0.23 & 3.77 & 0.33 & 3.87 & 0.32 & 3.93 & 0.32 \\
\hline ALP & $(\mathrm{IU} / \ell)$ & 11.52 & 2.56 & 9.63 & 1.23 & 10.53 & 0.91 & 9.83 & 0.45 \\
\hline GOT & $(\mathrm{IU} / \ell)$ & 54.48 & 10.34 & 51.05 & 9.74 & 55.50 & 5.10 & 58.10 & 8.68 \\
\hline GPT & $(\mathrm{IU} / \ell)$ & 30.73 & 3.71 & 29.48 & 3.99 & 29.83 & 4.86 & 34.60 & 3.39 \\
\hline $\mathrm{LDH}$ & $(\mathrm{IU} / \ell)$ & 433.28 & 84.12 & 328.97 & 115.59 & 493.63 & 77.81 & 492.37 & 87.00 \\
\hline $\mathrm{CK}$ & $(\mathrm{IU} / \ell)$ & 535.17 & 79.61 & 537.82 & 55.96 & 464.30 & 25.53 & 480.70 & 45.64 \\
\hline TG & $(\mathrm{mg} / \mathrm{d} \ell)$ & 38.53 & 7.61 & 52.20 & 8.80 & 35.73 & 6.23 & 49.23 & 1.90 \\
\hline Chol & $(\mathrm{mg} / \mathrm{d} \ell)$ & 36.87 & 9.64 & 40.22 & 10.53 & 34.33 & 9.01 & 39.63 & 5.26 \\
\hline Glu & $(\mathrm{mg} / \mathrm{d} \ell)$ & 169.15 & 27.98 & 195.77 & 18.17 & 152.87 & 21.52 & 148.03 & 5.67 \\
\hline CRP & $(\mathrm{mg} / \mathrm{d} \ell)$ & 0.03 & 0.05 & 0.05 & 0.05 & 0.07 & 0.06 & 0.00 & 0.00 \\
\hline UA & $(\mathrm{mg} / \mathrm{d} \ell)$ & 1.63 & 0.18 & 1.73 & 0.21 & 1.50 & 0.17 & 1.47 & 0.11 \\
\hline $\mathrm{Ca}$ & $(\mathrm{mg} / \mathrm{d} \ell)$ & 9.12 & 0.37 & 9.48 & 0.71 & 9.30 & 0.17 & 9.90 & 0.36 \\
\hline
\end{tabular}

きな血管, 末梢神経にも, 病理学的変化は認められなか った。又, 筋層と笳層内に存在している皮唐の付属器, 毛 (横断毛包, 毛髄質, 毛皮質, 毛小皮), 上皮性毛包, 結合組織性毛包, 毛球, 毛乳頭, 皮脂腺にも病変は認め られなかった（Fig. 11，12）。

\section{考察}

我々の生活環境はもちろんのこと, 実験動物の飼育環
境, 実験環境にも様々な高周波電磁界の発生源が存在す る。この高周波電磁界は, 実験動物の一般生理特性なら びに動物実験の成績になんらかの影響を及ぼしていると 予測され, 将来的には, 実験動物施設関係者の労衝衛生 上の問題としても捉えなければならないと思われるの で，その影響を明らかにすることを試みた。本研究は， その最初の報告である。又，近年盛んに用いられている 高周波電磁界を照射する健康器具の効果と安全性を推測 する基礎実験としても意義があると我々は考える。 
本研究においては，高周波電磁界照射による局所の微 小循環に対する影響を, ウサギ耳介の皮店表面温度, 血流量及び細動静脈血管径の変化を指標として検索し た。又, 局所の組織反応については, モルモットの側 腹部（Fig. 1）に高周波装置を30日間装着し，一般状 態, 体重, 血液生化学数值, 病理組織像等の変化によっ て検索した。なお，ウサギは非観血的に血行状態を観察 しやすく, 収縮期血圧が 95〜130mmHg, 払張期血圧が $60 \sim 90 \mathrm{mmHg}$ [16] とヒトに類似し, 循環器系の研究 に多く使われ，バックグラウンドデータも豊富であるこ と, 又, モルモットはアレルゲン感作率が高いことやヒ トの皮虙形態学的類似点 [16] が多く，これらの特徵が 広く局所刺激性試験等においてその有用性 [17] が認め られていること等の理由から, 供試動物としてそれぞれ 選択した。

ウサギを用いて定常環境下で行った実験から，高周波 電磁界照射直後より皮虐表面温度の上昇が認められ, 実 験群では照射前の雌雄個体の平均值と比較して0.93党高 い値を示した。実験群と対照群の差でみれば，皮庙表 面温度の上昇はさらに顕著で，照射開始 15 分後の平均値 で2. $60^{\circ} \mathrm{C}$ ，実験終了時（照射終了15分後）の平均值では 2. $70^{\circ} \mathrm{C}$ 差があった。この現象は，高周波電磁界が皮虚 表面温度の上昇をもたらすことに加えて，照射中止後の 温度低下が緩慢であり，照射効果の残存を示唆してい る。な拉，高周波装固作動 (ON/OFF) 時の音等による ウサギの情緒的血管反応の影響も考虑しなければならな いが, ON/OFF 作動を遠隔操作によったこと，その後 の皮膚表面温度にリバゥンド現象等もみられなかったこ とから，情緒反応要因の介在は考元難い。

皮虔表面温度の決定には多くの因子が関与している が，通常の温暖な環境下では，局所の血流量がもっとも 重要な因子とされている [6]。 Honda 5 [9] は, 一定 室温下のウサギ耳介において，皮虐表面温度と局所の血 流量が直線的な相関関係にあることを観察している。今 回の実験では統計学的に有意ではなかったが, 高周波電 磁界の照射によって局所血流量の增加傾向が認められ, ウサギ耳介における皮席表面温度上昇の主要な要因の 1 つは，高周波電磁界の照射による血流量の増加であった と推測できる。なお，高周波電磁界照射による体内分子 の摩擦亢進に基づく温熱効果も1つの要因かもしれない。

ところで，血流量増減の主な要因は，局所血管の払 張, 収縮である。大久保, 浅野 [21] は, 微細光電プレ シスモグラフィを用いた研究で, 高周波電磁界照射がウ サギ耳介の細動脈を搪張させることなく細静脈や毛細毛 管の血行を促進することを観察している。今回の実験で
も, ウサギ耳介の細静脈血管の拡張傾向は観察された が，細動脈血管の払張はみられなかったので，高周波電 磁界照射による血流量の増加は細静脈血管の拡張に由来 しているものと思われる。但し, 著者らは毛細血管につ いて検索を行っていないので, 局所血流量の増加に毛細 血管扗張がどの程度関与していたかは不明である。な お, 局所の加温が皮店温度受容器の興偪を介して反射性 の毛細血管扗張をもたらし, その結果, 局所の血流量増 加をきたすとい5 Halesら [8] の観察があるので, 高 周波電磁界の照射がまず局所の温度を上昇させ, 細静脈 の拡張そして血流量の増加を起こしたといら解釈も成り 立つ。

血管の扗張あるいは収縮には神経性, 体液性, その他 の要因が関与しているが 体夜性要因に関して三浦, 岡 田 [18] は, アンギオテンシン II，ノルアドレナリン, アルギニン，バゾプレッシン等の血管収縮物質の作用に 高周波電磁界は拮抗するとしている。神経性要因につい ては, Janig [12] は温度刺激によって血管収縮神経が, 入来 [10] はウサギ耳介の加温によって耳交感神経が， それぞれ抑制されることを観察しているけれどす，高周 波電磁界との関係を追求した研究はない，又，高周波電 磁界照射が血液粘性度の低下と血管扗張物質の生成をむ たらし，その結果，血流速度を高めて血流量を增加させ ていることも考えられるが，実験的な証拠はない。

ともあれ著者らは, 高周波電磁界照射によって明らか なウサギ耳介局所の皮膚表面温度の上昇を認め，細静脈 血管の拡張，局所の血流量の増加傾向も観察したが，細 動脈血管の払張は確認できなかった。これらの現象, つ まり温度上昇, 血流量增加, 血管拡張についての機序は 明らかにできなかったが，皮庙表面温度の上昇は一過性 でなく, 高周波電磁界照射による影響が持続的であるこ とは確実であった。

皮膚表面温度の上昇に影響を与えた局所微小循環の促 進は，一般に，組織への酸素や栄養物質等の供給および 老廃物質等の排除を促進させることになる。このような 現象が，おそらく高周波電磁界の照射による治療効果 $[2,5,22]$ として評価される要因であろ5。又, 近年, 炎症性疾患や老化における酸素フリーラジカル反応や酸 素ストレスの研究が進み, 細胞内外の $\mathrm{Ca}^{2+}$ に過酸化水 素生成を促進させる作用のあることが明らかにされてい る [4] が, 高周波電磁界に $\mathrm{Ca}^{2+}$ ブロッカー類似作用 [18] あるい愊甲状腺ホルモンの作用抑制効果 [13] 。 想定されているので，この方面に関する検討が必要である。 このように，高周波電磁界が及ぼす生体への影響は， 局所の皮庙表面温度の上昇等で確認され，局所的な電磁 
界の照射による生理学的作用は, 医療的応用が期待でき るものと考えられる。反面, 高周波電磁界が日常的に全 身に懪露されるような環境下では，体温上昇等の有害作 用 [23]，又，超音波や光，放射線等のエネルギーと電 磁界との複合作用 $[28,29]$ が報告されている。

そこで，著者らは30日間にわたって高周波装置をモル モットの皮店に直接接着させ, その安全性を検索した。 周波数 $9 \mathrm{MHz}$ の高周波電磁界に 1 日 8 時間, 計 30 日間 曝露されたモルモットの外観を含む行動, 体重, 飼料摂 取量, 各種血液生化学值, 諸臓器重量, 肉眼的ならびに 顕微鏡的病理所見について，観察した限りにおいて，対 照群との間に有意差は認められず，それらはすべて正常 モルモット值, 所見 $[16,19,24,25]$ の範囲内にあった。 特に, 高周波装置装着による外傷や火傷, 血液粘性変化 を示唆する $\mathrm{Ht}$ 值, 副甲状腺ホルモン動態に関わる $\mathrm{Ca}$ やALP 值等についても, 異常を認めなかった。又, 短 期間の高周波電磁界照射実験を終了したウサギについて も血液生化学的な検査を試みたが, 全く異常は認められ なかった。

しかし, Bawin ら [3]は, 鷄の脳を用いた研究で生 体に特異的な影響を与える特定周波数の存在を示唆して いることから, 高周波電磁界照射部位の拡大及び全身照 射により，複数の周波数帯で周波数ウィンドウ効果を検 索し, 生体に対する高周波電磁界の有用性ならびに安全 性について, 今後, 更に検討が必要と思われる。

\section{要 約}

高周波電磁界の生体に及ぼす影響を検索することを目 的として, 高周波電磁界の発生装置をウサギ耳介に装着 し, 赤外線サーモグラフィによる皮膚表面温度, レーザ ードップラー血流計による皮膚血流量, ビデオマクロス コープによる細動静脈血管径の変化を測定した。周波数 $9 \mathrm{MHz}$ の高周波電磁界15分間照射によって，局所の細 動脈血管の拡張は認められなかったが，明らかな皮虚表 面温度の持続的な上昇, ならびに, 細静脈血管の払張と 血流量の増加傾向が観察され, 微小循環の元進が確認さ れた。又，モルモットに対する高周波電磁界の有害作用 (周波数 $9 \mathrm{MHz}, 1$ 日 8 時間 $\times 30$ 日間照射) は, 一般行 動, 飼料摄取量, 体重, 葴器重量, 血液生化学值, 剖検 所見, 組織学的所見では認められなかった。

本研究では（株）オムロンライフサイェンス研究所の厚意に より, 同社の高周波電磁界発生装置を使用し, 又, 本装置に関 する数々の技術支援と助言を受けたことを明記し，関係者各位 に深謝する。

\section{文献}

［1］浅賀英世 (1988)，インフラアイ160の臨床的応用．BioMedical Thermology, 8, 7-9.

[2] Bassett. C.A.L., Pawlyk. R.J., and Pilla. A.A. (1974). Augmentation of bone repair by inductively coupled electromagnetic fields. Science, 184, 575-577.

[3] Bawin, S. M., Adey, W. R., and Sabbot, I. M. (1978). Ionic factors in release of ${ }^{45} \mathrm{Ca}^{*}$ from chicken cerebral tissue by electromagnetic fielde. Proc. Natl Sci USA 75, 6314-6318.

[4] Cadenas, E. and Boveris, A., (1980). Enhancement of hydrogen peroxide by protophores and ionophores in antimycin-supplemented mitochondria. Biochem J., 188, 31-37.

[5] Fenn, J. E. (1969). Effect of pulsed electromagnetic energy (Diapulse) on experimental hematomas. Canad Med Ass. J., 100, 251-254.

[6] 藤正 蟋(1983). コンピューター化サーモグラフィ・シ ステムによる生理機能画像診断法. CTS principles, 110.

[7] Ginsberg, A. (1940). Exhibited and demonstrated. In Fortnight on Infection, Ginsberg, A. (edit), New York Academyof Medicine, New York.

[8] Hales J. R. S., Iriki, M., Tsuchiya, K., and Kozawa, E. (1978). Thermally-induced cutaneous sympathetic activity related to blood flow through capillaries and arteriovenous anastomoses. Pflugers Arch, 375, 17-24.

[9] Honda, N., Carlson, L. D., and Judy, W. V. (1963). Skin temperature and blood flow in the rabbit ear. Am J. Physiol 204, 615-618.

[10］入来正躬（1986）。体表温の生理学的基礎一皮庙血流量 とその調節一. Biome dical Thermography, 6, 1-7.

[11] 板垣 博・大倉永治・伊藤昭吾・北村佐三郎 (1978) 実験用ウサギの生物学. 90-93，535-540, 板垣 博・ 大倉永治・伊藤昭吾・北村佐三郎, 訳, 文永堂, 東京.

[12] Jänig, W. (1985). Organization of the lumber sympathetic outflow to skeletal muscle and skin of the cat hindlimb and tail. Rev. Fhysiol Biochem Phar macol, 102, 121-213.

[13] Luben, R. A., Cain, C. D., Chen, M. C., Rosen, D. M., and Adey, W. R. (1982). Effects of electromagnetic stimulion bone and bone cells by low-energy lowfrequency fields. Proc. Natl Acad Sci USA 79, 4180-4184.

[14］末梢循環研究会 編 (1967). 末梢循環とその病態生理. 246 , 東京大学出版会, 東京.

[15] 松村 秩 (1987). 理学療法. pp. 127, 松村 秩編，医 菡薬出版, 東京.

[16] 松岡 理 (1980). 比較実験動物学概論. pp. 104-105, 253-254, 271-277, 280-296, 松岡 理編著, ソフトサ イェンス社, 東京.

[17］松岡 理・白須康彦 (1981). 新しい毒性試験と安全性 の評価. pp. 452-455, 松岡 理・白須康彦編, ソフト サイェンス社, 東京.

［18］三浦光彦・岡田淳一（1988）。バース卜型高周波電磁界 照射は血管収縮をブロックする. 北関東医学， 38，389396.

[19] 長瀬すみ・田中寿子（1976）. 実験動物の臨床生化学デ 一タ. pp. 205-216, 長瀬すみ・田中寿子編著, ソフト サイェンス社, 東京.

[20］中山昭雄 (1981). 温熱生理学. pp. 33-69, 126, 中山昭 雄編, 理工学社, 東京.

［21］大久保千代次・浅野牧茂（1988）。高周波パルス電磁界 
のウサギ耳介皮庙徽小循環に及ぼす影皘（1）。日本臨床 生理学会誌, 18, 407-412.

[22］西条一止・吉川恵士 ・宮本俊和 - 浅井克晏 - 松多邦雄 竹内二士夫・坂井友実・磯部八郎・宮本昭正 (1987) 高周波パルス電磁界のこりに対する治療効果. 医器学 誌, 57, 367-372.

［23］志賀 健・宮本博司・上野照剛（1991）磁場の生体人の 影錥. pp. 47-49, 志賀 健・宮本博司・上野照棡編著, てらべいあ, 東京.

[24] 鈴木 慗（1989）. 動物実験手技 II . pp. 31-34，75-78， 鈴木 製編，講談社サイエンティフィック，東京.

[25] 田嶋嘉雄 (1977). 実験動物学一技術編一。 pp. 77-78, 190-193, 田嶋嘉雄編集, 朝倉書店, 東京.

［26］玉川鉄雄 (1989). 電気治療学概論. pp. 157，182，健友 館, 東京.
[27] Tompkins, P. (1990). Hazards of electro-magnetic fields to human reproduction. Fertil Steril, 53, 185.

[28］上野照用（1983）。直流磁界の生体一及ぼす影箘。電気 学会マグネティックス研究会資料集, 83, 1-9.

[29］上野照剛（1984）。磁界の生体一及ほす影響一その作用 機構. 電気学会誌, 104, 87-89.

[30］上野照㴊 (1990)。磁界の生体効果と磁気刺激。日本応 用磁気学会研究会資料集， 67, 15-20.

[31] WHO. (1984). Environmental Health Criteria 16 "Radiofrequency and Microwave "(WHO and Internatl. Radiat. Prot. Ass.). Geneva, WHO.

[32] Wilson, B. W., Stevens, R. G., and Anderson, L. E. (1989). Neuroendocrine mediated effects of electromagnetic field exposure : possible role of the pineal gland. Life Sci, 45, 1319-1332.

\section{Explanation of Figures}

Fig. 5. Chanses of skin surface temperature of rabbits a : Before exposure to electromagntism $b$ : At the beginning exposure to electromagnetism $c$ : At the end of exposure to electromagnetism $\mathrm{d}$ : After exposure to electromagnetism

Fig. 11. Epidermis, dermis and hypodermis at the central site where a high frequency electromagnetism generator was attached a : Control : male b: Experimental group : male c: Experimental group : female (H. E. stain ; $\times 200$ )

Fig. 12. Blood vessels and peripheral nerves in the dermis and hypodermis at the central site where a high frequency electromagnetism generator was attached a: Control : female b : Control : female c : Experimental group : female $d$ : Experimental group: female $(H$. E. stain ; $\times 200$ ) 
高周波電磁界の影響
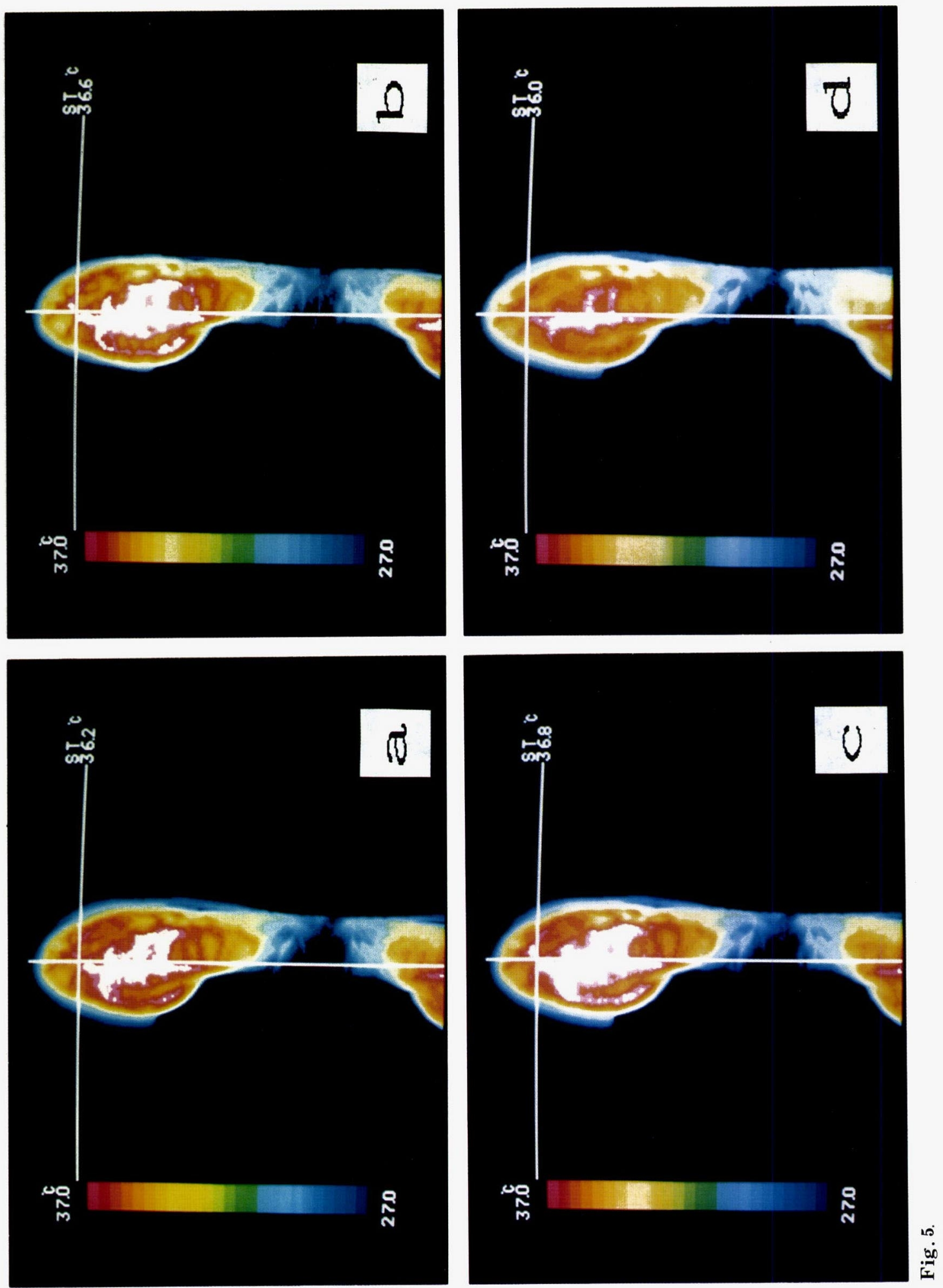

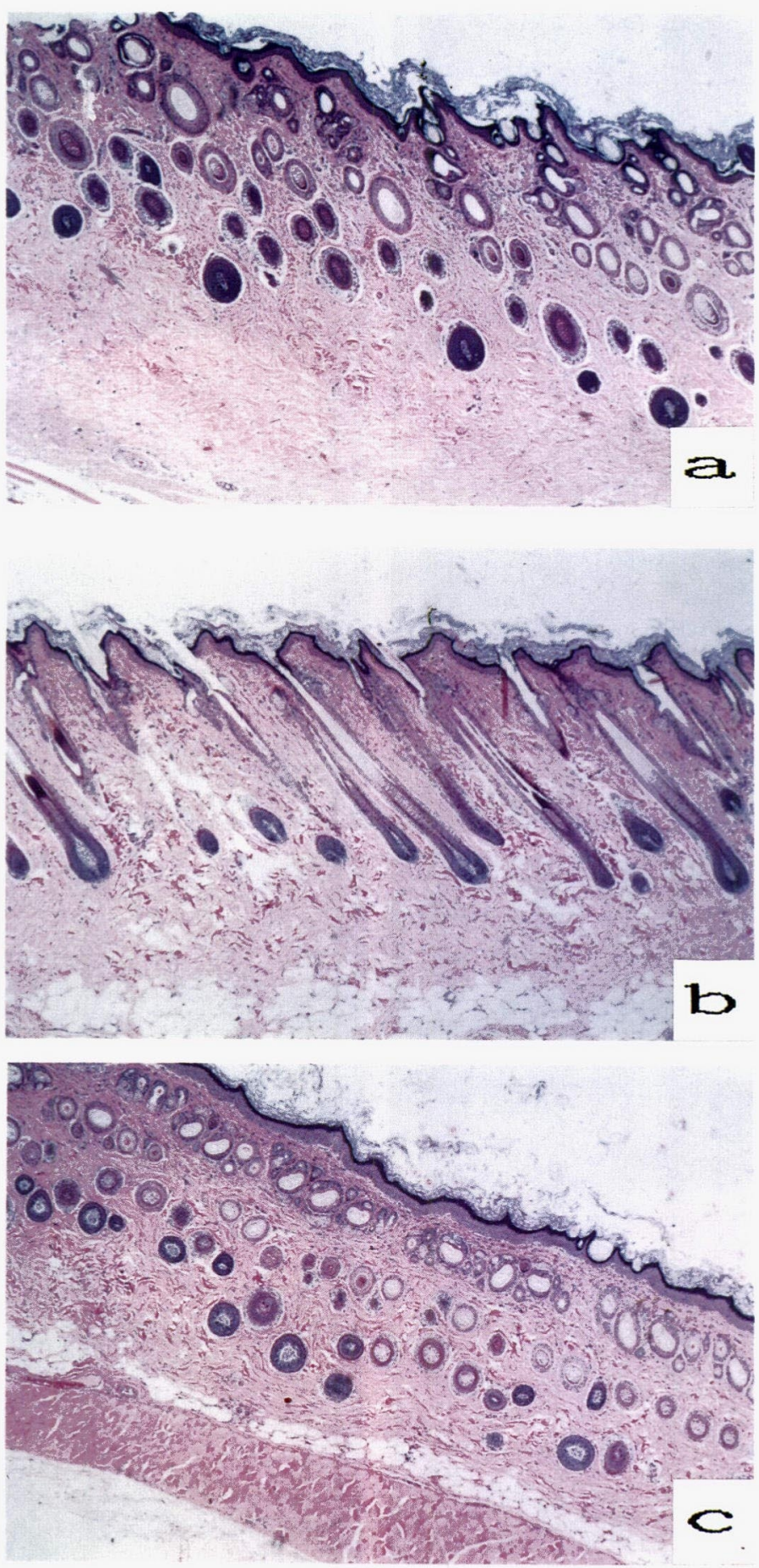

Fig. 11. 

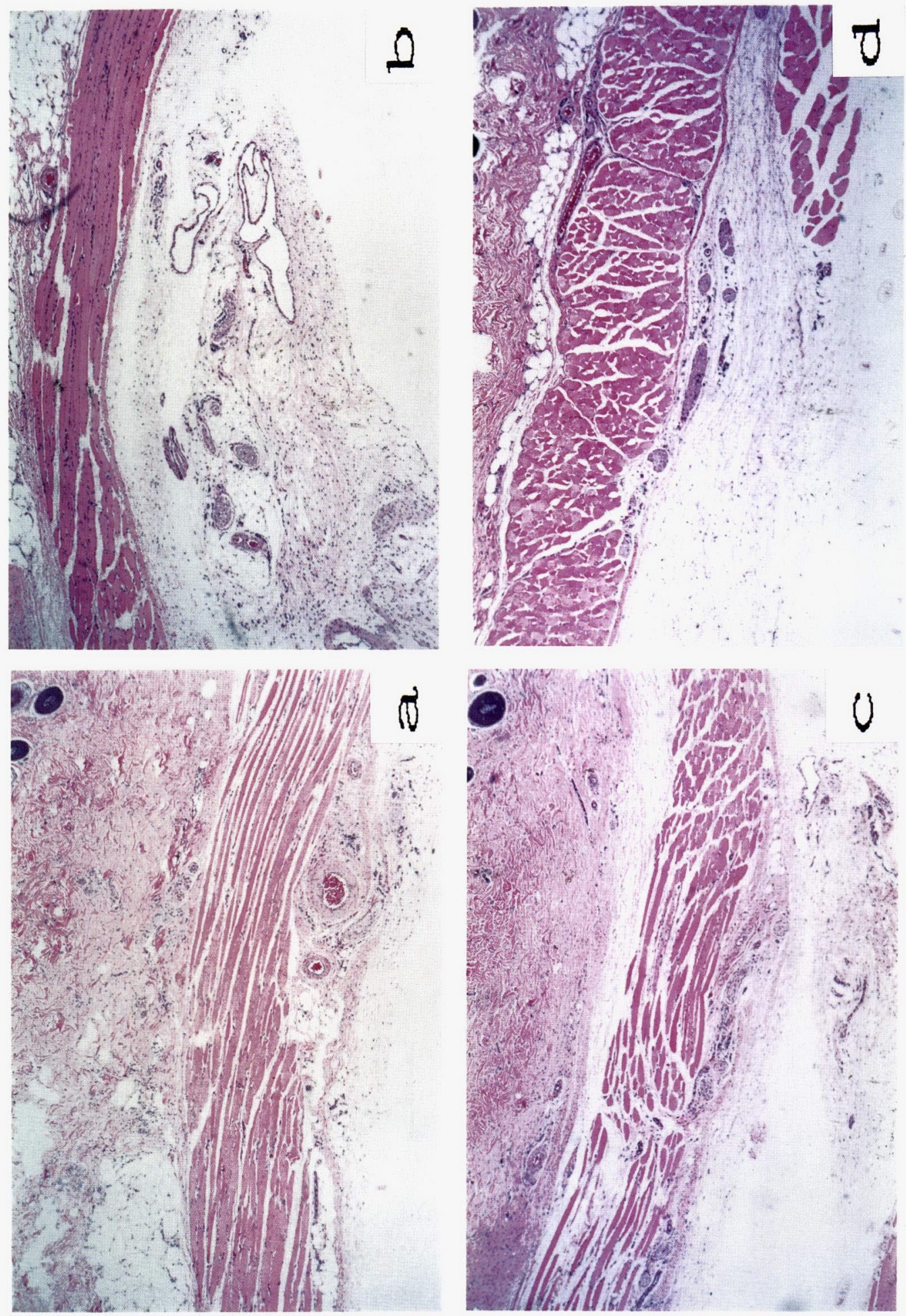